\title{
Application and coherence of the model of restorative justice in Europe
}

Antonio ludici*, Department of Philosophy, Sociology, Education and Applied Psychology, University of Padua, 35122 Padova, Italy

Laura Princivalli, Department of Philosophy, Sociology, Education and Applied Psychology, University of Padua, 35122 Padova, Italy

Elena Faccio, Department of Philosophy, Sociology, Education and Applied Psychology, University of Padua, 35122 Padova, Italy

Jessica Neri, Department of Philosophy, Sociology, Education and Applied Psychology, University of Padua, 35122 Padova, Italy

\section{Suggested Citation:}

ludici, A., Princivalli, L., Faccio, E. \& Neri. J. (2020). Application and coherence of the model of restorative justice in Europe. Global Journal of Sociology: Current Issues. 10(1), 01-08. https://doi.org/10.18844/gjs.v10i1.4750

Received December 15, 2019; revised February 20, 2020; accepted April 15, 2020.

Selection and peer review under responsibility Prof. Dr. Mustafa Gunduz, Cukurova University, Turkey.

${ }^{\circ} 2020$ Birlesik Dunya Yenilik Arastirma ve Yayincilik Merkezi. All rights reserved.

\begin{abstract}
Even in a spirited debate about its effectiveness and sustainability, restorative justice is now considered a new systematic legal proposal. The requirements of this meta-model include a criminal phenomenon through relational and inter-subjective reading, considering the crime in terms of injury to people. Also, they pose considerable attention to the needs of the victim and programme restorative actions on authors of the crime. This approach is sometimes considered difficult to apply. Starting from the legal environment to existing literature, this research investigates the coherence between the metatheoretical framework of reparative justice and some operational practices implemented in different European countries. With a systematic review of practices considered, it has outlined the state of the art of its application, describing critical issues and strengths, as well as providing important points, to be considered for theorists, professionals and experts involved in the development of alternative models to punishment.
\end{abstract}

Keywords: Restorative justice, penal justice, offender, victim, review.

\footnotetext{
* ADDRESS FOR CORRESPONDENCE: Antonio ludici, Department of Philosophy, Sociology, Education and Applied Psychology, University of Padua, 35122 Padova, Italy. E-mail address: antonio.iudici@unipd.it
} 


\section{Introduction}

Restorative justice represents, since nearly three decades, one of the most discussed and debated models of justice, in both areas of law and in scientific civil and social circles. The coexistence of different areas of interest involves considerable discussion concerning its presuppositions and especially a lively debate on its applicability. This is also strengthened by the political implications that its use entails, which depends on both safety conditions of the different states and on the way in which the use of punishment is theorised. Slowly rooted in popular imagination, the punishment is still considered as the only possible solution. The symbolic universe ${ }^{a}$ that revolves around the offender and punishment intended as deserved 'punishment' is based on a complex process of institutionalisation and legitimisation going from the revenge of the sovereign and carried on considering the imprisonment as an exclusive form of control and protection. However, in the late 1970 s, the need to go beyond mere punishment of the offender had risen, also in the light of very discouraging data in terms of the change of who commits a crime and for an extremely cost-utility budget deficit (Mazzucato \& Ceretti, 2008). Due to these requirements in the various international contexts, a new model of justice has found its way, the so-called restorative justice. This conceptual system offers a relational and inter-subjective reading of criminal phenomenon and a justice oriented to the protection of victims forcing to question both on justice, in general, and on the entire welfare system (Bazemore, 1998; Daly, 2002; Iudici \& Maiocchi, 2014; Johnstone \& Van Ness, 2007; Johnstone, 2013; Van Wormer, 2009; Zehr, 2015). Despite the lively debate on the sustainability of the paradigm, there are few studies on experiences that are able to represent systematic measures, probably due to the relative youth of the proposal. The present work intends to verify the implementation of certain principles that characterise the paradigm of reparative justice with regard to European studies carried out in various fields.

\section{Method}

\subsection{Aim}

Starting from what has been expressed in the Introduction section, this research has the purpose to provide a framework for the application of the principles of restorative justice in Europe; in particular, it will deepen the bond between the founding principles, the justice model proposed and the operational practices realised to date. Attention is drawn to how the theoretical principles of restorative justice are applied.

\subsection{Survey instrument: studies review}

Review analysis, in our case understood as 'studies review', takes into account a set of studies, on a certain topic, conducted in different times and places and with comparable methodologies. It is a search tool that aims to summarise data with a comprehensive review of the literature on a given topic and with attention to the sources, necessarily highly referenced, to identify, highlight and evaluate all the high-quality research evidences (Bilotta, Milner \& Boyd, 2014; Higgins \& Green, 2008; Petticrew \& Roberts, 2006; Silva, Grande, Martimbianco, Riera \& Carvalho, 2012).

\subsection{Sample survey}

The analysis of the literature above includes studies found using the following search engines: Scopus and Google Scholar. The keywords used to search these studies were 'restorative justice', 'justice', 'restoration', 'repair', 'mediation', 'effectiveness' and 'efficacy'. It also identified those

\footnotetext{
aSymbolic universe is intended as defined by Berger and Luckmann (1966, p. 61) that is 'the array of all socially objectified
} and subjectively real meanings'. 
researches containing explicitly the reference to the principles related to the model of reparative justice. Our review includes studies published from 2012 to 2017, coming from the European context and report on data collected between 2000 and 2010. Of these, all the works are carried out according to qualitative analyses, also in the case of use within the research of specific quantitative tools (statistical analysis, questionnaires or longitudinal analyses). All cases considered are at their first territorial application experience of the concept of restorative justice. Starting from the literature studies and from the objective of this work, which is to compare the application experiences with conceptual principles of the paradigm of restorative justice, the following criteria for analysis were identified: (1) the concreteness of the crime; (2) offender's obligation to remedy; (3) focus on the needs of the victim; (4) involvement of the victim, offender and/or community and (5) mediation/consensual solutions.

\section{Results}

\subsection{First criterion: the concreteness of the crime}

We can see that the research aim of Case 1 is the utility of alternative measures to detention. The crime is real and there is a search for a 'useful' solution. Case 2 is related to the use of restorative techniques used to address the problem of bullying. Cases 3 and 4 highlight the awareness of a lack of practice capable of intervening before a concrete and interpersonal damage: in the conclusion, there is the intention to 'lay the basis for critical reflection on the crime...'. Case 5 refers explicitly to the intersubjectivity of the crime: 'the offence has given rise to a position of asymmetry, an insult, a subtraction that can and should be reinstated'. Cases 6 and 7 highlight the importance of the concreteness of restorative justice which is already evident in the remedial activities offered. The same 'feeling circle' used in Case 8 allows a comparison between the actors involved and an awareness of the damage. The same principle is applied in Case 10, which tells of the awareness of what has happened, thanks to a direct comparison. In Case 9, most of the interviewed subjects (offenders) felt remorse and had the willingness to apologise for their previous behaviour. Case 11 starts from the premise that the deviant behaviour and the social situation of an offender measures can be taken in a meaningful way, to bring the offender back within society.' In Case 12, the offender "has to give his or her "word of honour" not to commit any further domestic violence and agree to participate in a special counselling/therapy programme'.

Table 1. Studies analysed

Study 1 Leonardi (2007) Le misure alternative alla detenzione tra reinserimento sociale e abbattimento della recidiva in Rassegna penitenziaria e criminologica n.2 Nuova Serie - Anno XI - MaggioAgosto, Ministero della Giustizia, Roma.

Study 2 Patrizi (2012) Giustizia riparativa come strumento di intervento nell'inclusione sociale di minori autori di reato e come modelli di intervento per la gestione di episodi di bullismo nelle scuole. Università degli Studi di Sassari.

Study 3 Ministero della Giustizia (2002) La giustizia riparativa e i centri di servizio sociale per adulti, Roma, Luglio 2002- Febbraio 2003.

Study 4 Ministero della Giustizia (2004) La prescrizione riparativa nell'affidamento in prova al servizio sociale; Roma, Luglio 2002 - Maggio 2004.

Study 5 Ministero della Giustizia (2000) Studio 'Mediazione e giustizia riparatoria nel sistema penale italiano'. Roma, 2000.

Study 6 Clerehugh (2010) Restorative practice - How young can we do? Streethouse School: our restorative practices experience; Wakefield, Streethouse School, May.

Study 7 Cook (2010) 'Beyond all belief' - Restorative practices at St. Edmund's Primary School, Norfolk, UK, Aprile, St. Edmund's Primary School, Norfolk.

Study 8 Mirsky (2010) Restorative Practices in Hungary - Transforming schools and prisons.

Study 9 Stamatakis and Vandeviver (2012), Restorative justice in Belgian prisons: the results of an empirical research, Crime, Law and Social Change 
ludici, A., Princivalli, L., Faccio, E. \& Neri. J. (2020). Application and coherence of the model of restorative justice in Europe. Global Journal of Sociology: Current Issues. 10(1), 01-08. https://doi.org/10.18844/gjs.v10i1.4750

Study 10 Elonheimo (2003). Restorative Justice theory and the finnish mediation practices. In A Paper Presented at the Third Annual Conference of European Society of Criminology, Helsinki (pp. 27-30).

Study 11 Vroomen and Pemberton (2014) Introducing Restorative Justice in the Netherlands, Lessons to be Learned from Neighbouring Countries Tilburg University

Study 12 Artinopoulou and Gavrielides (2012) Restorative Justice and Violence Against Women: Comparing Greece and The United Kingdom, Asian Journal of Criminology.

\subsection{Second criterion: commitment to remedy by the offender}

Case 1 searches for a practical application of the knowledge acquired by the offender in the rehab project. Case 2 presents some restorative techniques used in various fields: compliance with the rules $(16 \%)$, socialisation (14\%), prevention (11\%), democratic coexistence and awareness (10\%) and listening; then follows empowerment (8\%), containment of early school leaving (7\%), interpersonal communication (6\%) and conflict resolution (4\%). In Cases3 and 4, there is the prevalence of actions geared to the economical restoration and in the community, which shows a lack of clarity about the meaning of 'restoration' that seems to be intended just as a mere 'compensation' of the damage. The specific objective of Case 5 is to 'get to a restoration, because the crime has given rise to a position of asymmetry, an insult, a subtraction that can and should be reinstated'. In Case 6, the restorative programme implemented encouraged being responsible for one's own actions and to realise the consequences in transgressive kids. Cases 7 and 8 as restorative doctrine uses the feeling circle followed by mini weekly meetings and the briefing, with the presence of a mediator to facilitate the boys \girls towards awareness of their own actions and their consequences. In Case 9, the will to provide explanations and answers to the questions of the victims was the main reason for being willing to have individual meetings with the interested part. Case 10 contains 16 cases of mediation between the offender and victim where, given the positive results of this practice, the authors (of the crime) have proved to be more motivated to 'compensate the damage by implementing real prospects for victims to receive compensation'. Case 11 includes a vision of the offender's rights and needs and a form of reparation. Case 12 provides that the offender accepts a mediation process.

\subsection{Third criterion: focus on the needs of the victim}

Case 1 places in its assumptions the proposal for alternative justice, but its application is missing specific attention to the victim. Within Cases 3 and 4 is proclaimed a need for attention to the victims' needs, but none of the experiences mentioned in the mapping seems to apply it. Attention towards the victim is made in Case 2 framing the victims' needs from representations of teachers. In Case 5, the victim is contacted, informed and sustained, not at the end of the bureaucratic process, but along the legal way, from the very moment helshe underwent the offence. In Case 6, the victims were involved in the conference with their offenders, parents and mediators, so much so that one of the conclusions one speaks 'about adult management by children in disagreements between them'. Cases 7 and 8 deal with the victims who describe and express their feelings in the person, with the possibility of support from mediators or other companions. Case 9 is an investigation of the offenders. However, the victim's point of view is not present. Case 10 produces activities involving the victim. The description of the activities shows a clear change: from an initial state of anger and anxiety to a relaxed and reconciled sensation. Hence, the conclusion that generally 'the victims were raised to feel that there was no personal motive for the assault' (Elonheimo, 2003, p. 4). Case 11 includes a focus of the victim's right. In Case 12, there are family therapies, with the victim's involvement.

\subsection{Fourth criterion: involvement of victim-offender and/or community}

Case 1 concludes that, among other issues crossing the variables, 'there is a connection with the socio-economic characteristics of the territory'. Case 2 involves teachers and social workers in the 
observation and practice of restorative management of the problem and is considered the point of view of the offender. In Case 3, the use of the following principle is found between the procedures used: a) description of the universe of reference related to personal characteristics of the entrusted (age, marital status, gender, education, occupation, etc.).Case 4, in the first section of the questionnaire used, expressly asks for a 'description of the universe of reference, referred to the characteristics of personal entrusted'. Case 5 has a multifunctional system of service with respect to juvenile delinquency, specifically: a) an alternative definition of the office's intervention policy of Central Juvenile Ministry of Justice with the one made by all the other public and private institutions, including university, as well as study and research institutions involved in the problem of juvenile uneasiness. In Cases 6 and 7, the involvement of all affected figures takes place: following the creation of restorative practical, conferences were organised, in which, for the first time, both parents intervened on themes of responsibility and repair of the damage caused. Case 8 is also similar to Cases 6 and 7 and is aimed at the whole environment (parents, teachers and peers), which uses the strategy of conferences mediated by the staff. Case 9 presents the offender's point of view on the impact of the crime on the victims. As for Case 10, the cases of mediation presented demonstrate a clear involvement of all actors concerned so that conflict management has a positive solution and is based on shared responsibility. Case 11 shows how the political, social and economic systems influence the development of restorative justice. In Case 12, there is the family's involvement in therapy and in the total process.

\subsection{Fifth criterion: mediation/consensual solutions}

Case 1 deals with rehabilitative 'practices of which there is no evidence of work done with the victim, and neither of the idea of consensus in mediation activities'. The results of Case 2 show a real reduction of conflicts and an improved climate inside the class, thanks to restorative interventions, including in particular the reconciliatory discussions. In Case 3, there are significant initiatives towards the restoration taken directly from the convicted, presumably through defence attorney; and Case 4 states that the most common ways of implementation, with reference to helpful answers, are related to free activities for the general public (58\%) and the material and economic restoration (30.6\%), while free activities in favour of the injured party weigh only for $1.6 \%$. By examining the data of Case 5 , it is possible to see that in all reality, an increase in percentage of conclusions in successful mediation. Conferences used as an activity of restoration in Cases 6 and 7 show that engagement and dialogue, encouraged by a mediator, lead to a mutually acceptable solution of the conflict, bringing overall positive results, such as the use with children of a 'more adult' model to face up their disagreements and an approach towards the solution by the children and staff. The exercises and strategies carried out during the English studies are similar to the ones in Case 8, which demonstrate how children were already, 3 weeks after using the restorative model, actively involved in finding solutions that could be shared. Most of the offenders of Case 9 were willing to meet with the victims. In Case 10, the results show that 13 out of 16 mediations carried out have found a stable agreement, as a result of some meetings. The conclusion of Case 11 is: 'This is not a technique but a process that asks commitment from all parties involved' (Vroomen \& Pemberton, 2014). Case 12 shows exceptional results in comparison to other European countries.

\section{Discussion}

The project experiences considered have shared some of the basic principles inherent to the restorative justice paradigm. The description of how these principles have been applied has highlighted some significant data. Referring to the principle of 'concreteness of the crime', three studies out of 12 do not meet this criterion; in such cases, reference is made to the offence only in abstract terms or general reflection; however, there are no specific and operational forms. Therefore, the current difficulty is to concrete the crime in suitable actions (and behaviours), settling mostly on general concepts. The opportunity to define the crime in 'relational' terms appears very difficult and 
requires a cognitive effort, regulatory but also an operating comparison on the practical implications of the crime itself. With reference to the principle of 'commitment to repair by the offender', there are four out of 12 cases where there is no effective application of the criterion above. What seems to be the limit of some studies is the real empowerment of the offender towards his \her actions, with the consequence to elaborate the offence only in punitive terms. In the rest of the studies, some strategies for the involvement of the authors of the crime are identified. With respect to the criterion 'victim's need', in at least six studies no concrete actions are reported. For example, in some cases, the victim's needs are considered only on a symbolic and not effective level. With reference to literature, we can assume that this difficulty is due to cultural reasons; in fact, it is believed that the best way to protect the victim is to distance him \her from the offender or other dangerous situations, exchanging the 'distance' as a therapeutic solution. In the rest of the studies, the victim is involved even with various difficulties. With reference to the active involvement of the victim, offender and/or community, we found more or less the same results of data emerging from above: in at least six cases, there is any involvement of all relevant actors. Moreover, there is also a difficulty in engaging the community, which is understood as a set of roles and resources able to provide opportunities to socialise (Case 10). With reference to the preference for consensual solutions in four cases out of 12 , we find a lack of achievement of objectives, or indeed, in some studies, there is a theoretical need to develop a correct reflection on crime and on its consequences, but there is no evidence of agreements or products really shared, from which it is possible to understand a real difficulty in application. Finding shared solutions still remains a difficult skill to accomplish, in relation to the overcoming of certain prejudices, bound to the victim but also to the offender. However, in some projects, it has been possible, but to experience this process as child, this can develop a more prone mind set to culture of co responsibility.

\section{Conclusion and recommendations}

Starting from studies in the literature, which highlighted a potential gap between theoretical assumptions and application experiences, this work has focused on detecting the level of consistency between the theoretical framework of restorative justice and its own applications. According to the studies taken into account, we note a substantial consistent application of the principles of restorative justice, with the result of having obtained different results: a 'conflict reduction and better relations' (Iudici, Vallorani \& Antonello, 2013; Patrizi, 2012), an increase in the emotional literacy and in the 'ability to express feelings', an increase of maturity, a great attitude towards learning, a greater cohesion in classroom, an increase in problem-solving, in both under-ages and in the staff (Cook, 2010). The difficulties in applying the theoretical principles are different, many of which are confirmed by the literature. For example, many of the participants have laboriously understood the idea of reconciling the relationship between the offender and the victim. Many of the victims claim the punishment and the authors of the crime, on the one hand, deny their faults trying to justify their own behaviour (Daly, 2003); on the other hand, they passively await the punishment due. There is, therefore, no familiarity with the concept of mediation, for example, the victims do not always recognise the neutrality of the mediator's role, preferring to leave the problem to the judicial authorities. Finally, being governed in the judicial proceedings (sometimes referred to by magistrates), mediation is perceived as an 'imposed' legal instrument, rather than an opportunity for reconsidering the relationship between the victim and the offender. Very often also are such evidences that measure the effectiveness of repair rather than the punitive model, without considering that the two models are not necessarily antagonistic, while moving on very different plans. In most experiments, the restorative perspective does not see in the pain an imitation of violence, neither the mere application of a rule, but the suggestion to 'restore the dialogic dimension, inter-subjective balance in which each subject relates to each other not as an opposed but as a mutual' (ludici, Alborghett \& Ferri, 2017; Iudici, Boccato \& Faccio, 2018; Reggio, 2010).Many cases include restorative actions, but it is not clear how they take place, giving the idea that the action is in itself restorative. In other works, the intention to repair or make a reflection on the crime is expressed, in ways that most recall a 
paternalistic behaviour rather than real change. In many studies, the contact between victim and offender is symbolic, and this leads to a reflection on what level of repair is required and useful. Another critical aspect is the victim's involvement, which is often theorised but not divided into specific and verifiable actions. Especially, the outcome of this path is unclear and in some cases there is the impression that the distress of the victim had been reified. Surely there is more to do, to make consistent the application of theoretical references, for example, making the range of experimentation wider, so to further stimulate the cognitive and practical-theoretical debate. What is certain is that the theoretical debate on the coherence of the paradigm is still open and does not lead to any definitive conclusion, but, at this early stage, as Pavlich (2006) suggests, we should not expect them, namely different approaches coexist in justice today.

\section{References}

Artinopoulou, V. \& Gavrielides T. (2012). Restorative justice and violence against women: comparing greece and the United Kingdom. Asian Journal of Criminology.

Barnett, R. E. (1977).Restitution: a new paradigm of criminal justice.Ethics, 87, 279-301.

Bazemore, G. (1998). 'Restorative justice and earned redemption communities, victims, and offender reintegration'. American Behavioral Scientist, 41(6), 768-813.

Berger, P. L. \& Luckmann, T. (1966).The social construction of reality. Garden City, NY: Anchor Books (trad. it., 1969 La realtà come costruzione sociale, Bologna, Italy: II Mulino).

Bianchi, H. (2010). Justice as sanctuary. Eugene, OR: Wipf and Stock Publishers.

Bilotta, G. S., Milner, A. M. \& Boyd, I. (2014).On the use of systematic reviews to inform environmental policies. Environmental Science and Policy, 42, 67-77.

Cavalla, F. (1998). La pena come riparazione. Oltre la concezione liberale dello stato: per una teoria radicale della pena (pp. 1-109). Padova, Italy: Aa. Vv. Pena e riparazione.

Clerehugh, C. (2010). Restorative practice - How young can we do? Street house school: our restorative practices experience. Wakefield, UK: Street house School.

Cook, L. (2010). "Beyond all belief" - restorative practices at St. edmund's primary school. Norfolk, UK: Aprile; Norfolk, UK: St. Edmund's Primary School.

Daly, K. (2002). Restorative justice the real story. Punishment and Society, 4(1), 55-79.

Daly, K. (2003). Mind the gap: restorative justice in theory and practice. In A.von Hirsch, J. Roberts, A.E. Bottoms, K. Roach \& M. Scihff (Eds.), Restorative justice criminal justice: corpeting or reconcilable paradigms? (pp. 219-236). Oxford, UK: Hart.

Elonheimo, H. (2003). Restorative justice theory and the finnish mediation practices (pp. 27-30). In A paper presented at the third annual conference of European society of criminology, Helsinki, Finland.

Higgins, J. P. \& Green, S. (Eds.). (2008). Cochrane handbook for systematic reviews of interventions (Vol. 5). Chichester, UK: Wiley-Blackwell.

ludici, A. \& Maiocchi, A. (2014). Community Justice and juvenile offender: the management of an individual case with criminal slope with community involvement. Mediterranean Journal of Social Sciences, 5(20), 20152027.

ludici, A. Alborghetti, E. \& Ferri, C. (2017). Mediation as a restorative justice tool: applications in the Italian juvenile judicial context. In E. Jessica (Ed.), Restorative and transitional justice: perspectives, progress and considerations for the future (Chap 5., pp. 221-226). Hauppauge, NY: Nova Science Publishers. ISBN: 978-1-53610-688-6.

ludici, A., Boccato, F. \& Faccio, E. (2018). Perspectives on reoffenders: the views of detainees, the general public and those working with offenders. International Journal for Crime, Justice and Social Democracy, 7(1), 60-75. doi:10.5204/ijcjsd.v7i1.356.

ludici, A., Vallorani, M. \& Antonello, A. (2013). Innovative law old services: application and limitations in the application of restorative justice in Italy: description and analysis of a case study. International Journal of Innovation and Applied Studies, 4(1), 43-51.

Johnstone, G. \& Van Ness, D. W. (2007). Handbook of restorative justice. Cullompton, UK: Willan Publishing. 
Leonardi, F. (2007). Le misure alternative alla detenzione tra reinserimento sociale e abbattimento della recidiva in Rassegna penitenziaria e criminologica n.2.Roma, Italy: Nuova Serie - Anno XI -Maggio-Agosto, Ministero della Giustizia.

Mazzucato, C. \& Ceretti, A. (2008). Mediazione reo/vittima: le" istruzioni per l'uso" del Consiglio D’Europa. Un commento alle" Guidelines for a Better Implementation of the Existing Recommendation concerning Mediation in Penal Matters". Nuove Esperienze Di Giustizia Minorile, (1), 201-209.

Ministero della Giustizia. (2000). Studio Mediazione e giustizia riparatoria nel sistema penale italiano. Amsterdam, Netherlands: Roma, 2000.

Ministero della Giustizia. (2002). La giustizia riparativa e $i$ centri di servizio sociale per adulti.Amsterdam, Netherlands:Roma, Luglio 2002-Febbraio 2003.

Ministero della Giustizia. (2004). La prescrizione riparativa nell'affidamento in prova al servizio sociale. Amsterdam, Netherlands: Roma, Luglio 2002-Maggio 2004.

Mirsky, L. (2011). Restorative practices: giving everyone a voice to create safer saner school communities. The Prevention Researcher, 18(5), 3-6.

Patrizi, P. (2012). Giustizia riparativa come strumento di intervento nell'inclusione sociale di minori autori di reato e come modelli di intervento per la gestione di episodi di bullismo nelle scuole. Sassari, Italy: Università degli Studi di Sassari.

Petticrew, M. \& Roberts, H. (2006). Systematic reviews in the social sciences. Hoboken, NJ: Wiley Blackwell.

Reggio, F. (2010). Giustizia dialogica, luci e ombre della restorative justice. Milan, Italy: Franco Angeli.

Stamatakis, N. \& Vandeviver, C. (2012).Restorative justice in Belgian prisons: the results of an empirical research.Crime, Law and Social Change.

Van Ness, D. W. \& Strong, K. H. (2006).Restoring justice: an introduction to restorative justice. London, UK: LexisNexis.

Van Wormer, K. (2009).Restorative justice as social justice for victims of gendered violence: a standpoint feminist perspective. Social Work, 54(2), 107-116.

Vroomen, A. \& Pemberton, A. (2014). Introducing restorative justice in the Netherlands, lessons to be learned from neighbouring countries. Tilburg, Netherlands: Tilburg University.

Zehr, H. (2015). The little book of restorative justice: revised and updated. New York, NY: Skyhorse Publishing, Inc. 